\title{
The Impact of Common External Tariffs on Household's Welfare in a Rich African Country with Poor People
}

\author{
Olayinka Idowu Kareem
}

\author{
Alexander von Humboldt Stiftung, University of Marburg, Germany
}

Copyright $\mathrm{C} 2018$ by authors, all rights reserved. Authors agree that this article remains permanently open access under the terms of the Creative Commons Attribution License 4.0 International License

\begin{abstract}
The poverty impact of trade policy has been ambiguous because of their differential effects on economic agents due to the transmission mechanism through which they operate. In this context, this paper uses Nigeria's micro- and macro-economic data to investigate the poverty effects of Common External Tariff (CET) of the Economic Community of West African States (ECOWAS). The poverty effects were evaluated from the perspective of households as producers and consumers. The empirical strategy proceeds with two steps: first, by determining the extent of the tariff pass-through to domestic prices; and lastly, evaluating the impact of the price change on household welfare. The findings indicate that domestic prices declined due to the higher tariff pass-through. This decline was higher in states closer to ports and borders, which face lower trade costs. The ECOWAS CET had net positive effects on the welfare of households, largely due to the gains from the expenditure basket. The expenditure gains from the adoption of the trade policy outweigh losses incurred in their purchasing power through lower income. Therefore, this study provides evidence that the price transmission mechanism, household characteristics and geographical location are important determinants in assessing trade policy effects in Nigeria.
\end{abstract}

Keywords Common External Tariffs, Distribution Effects, Micro and Macro Data, Nigeria

JEL Classification: C01, C23, F13

\section{Introduction}

The improvement in overall welfare of the people is often the prime objective of any government. In attaining this, there is the need to strike balance with other macroeconomic objectives through complementary policies, which sometimes is difficult to achieve. The conflict in the attainment of macroeconomic goals is obvious in some countries, especially in Africa, where economic growth is not accompanied with improvement in people's welfare. Nigeria has experienced continuous growth, averaging $7 \%$ in the last five years, without corresponding structural transformation in infrastructure and human development. This reinforces the paradox of a rich country with poor people that Nigeria is said to be (World Bank, [1]). For instance, unemployment rate reached $25 \%$ in 2014 (NBS, [2]), while the share of population living below the poverty line has increased from $43 \%$ in 1985 to $45 \%$ in 2010 (World Bank, [3]). To explain this situation requires a critical analysis of government policies and their effects. Specifically, this study sheds light to the trade policy dimension of government policies, and analyzes the impact on households' welfare of the adoption of Economic Community of West African States' Common External Tariffs (ECOWAS-CET).

Nigeria adopted ECOWAS-CET in 2005 as a means of further integration of the economy into global market, particularly in the ECOWAS sub-region. This reduces tariff rates from $0 \%-150 \%$ to $0 \%-50 \%$ during the transition period of 2006-2007. These tariffs stand as ECOWAS most favoured nation (MFN) rates to non-member countries and are part of the trade liberalization scheme (TLS) aimed at enhancing the sub-regional trade integration. Four tariff bands are established by ECOWAS-CET, namely $0 \%$ for social and necessities, 5\% for raw materials, $10 \%$ for intermediate goods and $20 \%$ for finished goods that are not produced locally. Nigeria was granted a fifth band of 35\% for finished goods manufactured locally.

The effects of ECOWAS-CET across all the segments of the society will depend on whether the households are net consumer or producer of commodities. A perusal of the literature indicates that the transmission mechanism and poverty impact of this trade policy are usually uncertain. The different pass-through mechanisms upon which the trade policies operate are usually responsible for variation of their impact. Usually, trade policies are reflected in local price changes and returns to factors, which in turn have effects on the consumption and production decisions of the 
households (Nicita, [4, 5]; Marchand, [6]; Topalova, [7, 8]; Porto, [9]; Castiliho et al., [10]). In this context, this paper asks the following questions: To what extent as the ECOWAS-CET affected domestic prices? And what have been the effects of price changes on households' welfare? It is from this that this study draws its objective, which is to empirically investigate the poverty effects of the ECOWAS-CET in Nigeria.

A perusal of the literature shows that there is wide range of analyses in the literature on the poverty and inequality impact of globalization; however, only very few studies are available evaluating the trade policy impact of the ECOWAS-CET in Nigeria. Balogun and Dauda [11], Urama et al. [12], Odu [13], Oyejide [14], and Nwafor [15] look only at the macroeconomic impact of the CET on Nigeria. The potential distributional impact has been examined exclusively through ex-ante studies: Nwafor et al. [16] use a Computable General Equilibrium (CGE) model to examine the potential impact of adoption of the CET on rural and urban poverty, Marchat and Rajhi [17] and Soludo and Oji [18] conduct ex-ante analyses at the sectoral and household levels. An ex-post analysis was carried out using a hybrid model of Marchand and Nicita in the manufacturing and agricultural sectors by Kareem [19]. There are few if any ex-post studies that examine the poverty and inequality effects of the ECOWAS-CET on Nigerian households using data from the agricultural sector. Thus, this paper fills this gap by analysing the poverty impact of the ECOWAS-CET on Nigeria's households through an ex-post econometric analysis using both macro and household survey data.

\subsection{Literature Review}

A perusal of the literature shows that there are many studies examining the effects of globalization or trade liberalization on different economies at the national, sectoral and household level. Many of studies are conducted for developing countries (Isik-Dikmelik [20]; Sheshan [21]; Tapolova [7]; Porto [9]; Castilho et al. [22]; Nicita [4]; Hanson [23]; Marchand [6]; Shuaib [24]; Castilho et al. [25]) and conclude that trade labialization has overall positive effects on economic growth. Empirical studies on the distribution of these effects, however, suggest that the benefits are usually unevenly distributed across regions, sectors and households (Sheshan [26]; Porto [27]; Castilho et al. [22]; Nicita [5]; Boysen [28]; Gourdon et al. [29]; Ianchovichina et al. [30]; Kareem [19, 31]). Some of these studies used ex-ante analysis, which allows them to simulate the likely or potential impact of any shock in trade policy on different geographical regions, sectors, and households (Boysen [28]; Benjamin and Deaton [32]; Porto [27]; Chen and Ravillon [33], Bussolo et al. [34]). For instance, Nwafor et al [16] examines the effects of import tariffs reduction on poverty and income distribution in Nigeria. A dynamic CGE model was used to simulate whether there will be increase in the overall incidences of poverty and uneven impact on household income distribution. The findings indicate a slight reduction in real income in the short run trade liberalization. However, when tariffs are change to the proposed ECOWAS tariff regime, the result shows that real income of urban and rural areas increase at a higher rate compared to the trade liberalization regime. Although, the impact is slightly negative for both rural and urban areas in the first year, but after this year, both incomes increase at a faster rate with the ECOWAS tariff regime.

Ianchovichina et al. [30] adopt a two-step computational simple procedure to analyze the effects of Mexico' potential unilateral tariff liberalization. The study uses a CGE model and applies the price changes to Mexican household data to assess the effects of the simulated policy on poverty and income distribution. Besides, they choose GTAP as the price generator, the paper model Mexico's differential tariff structure appropriately. The result indicates that tariff reform will have a positive effect on welfare for all expenditure deciles. Base on the assumption of non-homothetic individual preferences, trade liberalization benefits people in the poorer deciles more than those in the richer ones. An integrated microsimulation CGE model was adopted by Shuaib [24] with an aggregated 2006 social accounting matrix and 2003/2004 Nigeria Living Standard Survey to determine the effects of trade liberalization on poverty in Nigeria. His simulated results indicate a moderate poverty-reducing effect of agriculture and manufacturing sectors trade liberalization, in which the effect is relatively more pronounced in the urban centres. A comprehensive literature review was conducted by de Arce et al. [35] on the impact of trade liberalization on poverty in Sub-Saharan Africa with a general equilibrium framework. They examine studies that link liberalization to poverty, while describing the basic and extended structure of computable general equilibrium (CGE) models with the pros and cons. The outcome of the review indicates that most of the studies conclude that, though, trade liberalization has positive effects on poverty in the long run, it has a short run negative effect.

In evaluating the impact of trade liberalization on households over certain period, studies such as Nicita $[4,5]$, Marchard [6], Isik-Dikmelik [20], Sheshan [21], Castilho et al. [22], Hanson [23], Castilho et al. [25] use instead ex-post analytical methods. Goff and Singh [36] evaluate whether the effects of openness on poverty varies with some country characteristics and testing for non-linearity in the trade-poverty relationship using a panel of African countries over the period $1980-2010$. The finding indicates that trade openness tends to reduce poverty in countries where the financial sectors are deep education level is high and with strong institutions. Furthermore, Seck, et al. [37] determine the importance of non-tariff barriers (NTBs) to agricultural trade within ECOWAS using a gravity model. Besides, a survey of truckers in Tambacounda, Senegal was carried out in 2009 to find that there was extensive bribery by policy and border officials, 
effectively representing a barrier to trading. Beyond this, the empirical result shows that agricultural trade among the countries of ECOWAS is higher than one would expect. They opined that it does not mean that there are no NTB within ECOWAS, but it does imply that any such barriers are less harmful to agricultural trade in ECOWAS than in the world. Most of these studies conclude that trade liberalization has resulted in the increase of wage inequality and agricultural products' price reduction.

Despite the large diffusion in the literature of analyses on the distributional impact of trade liberalization, only scanty studies are available evaluating the trade liberalization policy of ECOWAS' CET in Nigeria. Balogun and Dauda [11], Urama et al [12], Odu [13], Ajayi and Osafo-Kwaako [38], Oyejide [14], Nwafor [15] look simply at the macroeconomic impact of CET on Nigeria. While the potential distributional impact has been assessed exclusively through ex-ante studies: Nwafor et al. (2005) use a CGE model to examine the potential impact of adoption of CET on rural and urban poverty, and Marchat and Rajhi [17], Soludo and Oji [18], Kuji [39] propose ex-ante analyses at sectoral and household levels. There is little or no ex-post study that examines the distributional effects of ECOWAS' CET on households in Nigeria or the level of tariff pass through into domestic prices in Nigeria except the novel study of Kareem [19]. An ex-post analysis of the impact of ECOWAS-CET on households' welfare was carried out by Kareem [19], which conclude that the overall net welfare effect of CET is positive in both agriculture and manufacture sectors. Thus, this study contributes to the frontier of knowledge by analyzing the impact of ECOWAS CET in the agricultural sector on Nigeria households' welfare through an ex-post econometric analysis using the combination of macro data and households' surveys.

\section{Material and Methods}

This study adopts the methodological approach of Nicita [5] to measure the effects of ECOWAS' CET on households' welfare through domestic price changes. First, I examine the impact of ECOWAS-CET on domestic prices; then analyzed the effect of price changes on households' poverty.

\subsection{Tariffs Pass-through Model}

This empirical strategy makes some specific assumptions for the model. It is assumed that consumer goods are not differentiated by origin, and that their prices are at average levels of imported and domestic producer prices. Also, an assumption is made that trade costs only affect imported goods. Thus, the retail price that households face by consuming a good $g$ at time $t$ in state $s$, $P_{g t s}$, will depend on the domestic producer prices of the good $\left(P P_{g t s}^{\alpha}\right)$, the international price in domestic currency $\left(P^{*}\right)$, tariffs $\left(\tau_{g t}\right)$ and trade costs $\left(T C_{g t s}\right)$, which is written as:

$$
P_{g t s}=P P_{g t s}^{\alpha}\left(P^{*}\left(1+\tau_{g t}\right) T C_{g t s}\right)^{1-\alpha},
$$

Where $\alpha$ measures the extent to which the local varieties dominate the imported ones, $1-\alpha$ is the pass-through, which indicates the extent to which international prices, tariffs, and trade costs affect domestic prices. If $\alpha=0$, then there is a complete pass-through and the full extent of the border price changes is reflected in the consumer prices, which is likely to occur when no local production exists. If $\alpha=1$, then the pass-through is nil, indicating that there is no effect of border price changes on the price of goods paid by consumers, which corresponds to a situation of relative autarky where domestic markets are dominated by local producers. Equation (2) presents the linearized form of equation (1).

$$
\text { In } P_{g t s}=\alpha \operatorname{InP} P_{g t s}+(1-\alpha) \operatorname{In} P^{*}+(1-\alpha) \operatorname{In}\left(1+\tau_{g t}\right)+(1-\alpha) \operatorname{In} T C_{g t s}
$$

Following Nicita [5] specification, an unrestricted form of Equation (2) is assumed, which gives the following specification:

$$
\text { In } P_{g t s}=\beta_{0}+\beta_{1} \operatorname{InP} P_{g t s}+\beta_{2} \operatorname{In} P^{*}+\beta_{3} \operatorname{In} T C_{g t s}+\gamma \operatorname{In}\left(1+\tau_{g t}\right)+\varepsilon_{g t s} .
$$

In equation (3), distance is used as a proxy for trade costs. The shortest distance to the nearest main port of entry is used. Thus, in line with this paper's objective of distilling the effect of trade policy on domestic prices at the state level, the empirical strategy includes an interaction term between distance and the tariff rate in the final equation specified. This is to isolate the domestic impact of tariff changes in the pass-through. Thus, in line with Nicita [5], the following econometric specification is adopted to estimate the tariff pass-through effect in the case of Nigeria:

$$
\begin{aligned}
& \text { In } P_{g t s}=\beta_{0}+\beta_{1} I n P P_{g t s}+\beta_{2} \operatorname{In} P^{*}+\beta_{3} I n T C_{g t s}+\beta_{4} \operatorname{In}\left(1+\tau_{g t}\right)+ \\
+ & \beta_{5} \operatorname{In}\left(1+\tau_{g t}\right) T C_{g t s}+\beta_{6}\left(\operatorname{In}\left(1+\tau_{g t}\right) T C_{g t s}\right)^{2}++\pi_{t}+\varepsilon_{g t s},
\end{aligned}
$$

where $P_{g t s}$ represents the domestic price of good $g$ in states at time $t, P P_{g t s}$ is the producer price of the good, $P^{*}{ }_{g t}$ is the world price, $T C_{g s t}$ is the trade cost, $\tau_{g t}$ is the tariff, $\mu_{s}$ stands for state fixed effects to control for regional price differences, $\pi_{t}$ are time fixed effects, and $\varepsilon_{g s t}$ is the error term. The study assumes that the error term does not include factors that affect tariffs and prices simultaneously controlling for time. 
Many models of reduced-form often assume a perfect pass-through, that is, changes in tariffs perfectly transmitted to domestic prices, and thus to households. There are plenty of market imperfections and transaction costs, however, that may affect this transmission chain and explain the absence of clear empirical results in line with the theoretical predictions. This is especially the case in developing countries such as Nigeria, where geographical locations and domestic markets are highly segmented.

\subsection{Poverty Impact Model}

Analysis in this sub-section examines the impact of the ECOWAS-CET on Nigerian households by focusing on the price changes of the traded goods. The specific results regarding the welfare effects of trade liberalization in geopolitical zones and states are presented in Table 3.

In Nigeria, many of the households are usually consumers and producers of goods, thus, it is important to recognized these roles of the household when analysing any policy impact on household's welfare ${ }^{1}$. Generally, the income from sales constitutes the larger proportion of household income because sales of agricultural and non-farm goods constitute the larger proportion of household income. In the rural areas, agricultural sales often constitute the bulk of the income to the household. However, in the urban areas, income from agricultural sales constitutes the low proportion of household income. Expenditure on agriculture, especially food items often form bulk of the household expenses.

The welfare model is specified to estimate the effects of trade policy on household welfare. This specification modifies the models of Porto [9], Nicita [5], and Marchand [6], which indicate that changes in utility $d U_{h s}$ of household $h$ in states depend on the changes in domestic prices, agricultural production, and consumption.

$$
d U_{h s}=\sum_{g} \theta_{h g}^{x} d P_{g s}-\sum_{g} \theta_{h g}^{c} d P_{g s}
$$

where $\theta_{h g}^{c}$ is the income share spent on good $g$ by household $h, \theta_{h g}^{x}$ is the income share obtained from selling goods produced at price $P$, and $d P_{g s}$ is change in prices. Aggregate welfare, which is taken to be the sum of poverty in the households, is therefore given by the sum of the welfare of all households. Thus, households' exposure to change in price will depend on their expenditure allocation. The calculation for each household was done with consideration to expenditure and income, and given the fact that the price effects estimation was differentiated by states. Aggregating the results across household, the study finds that the effects of ECOWAS-CET on households in Nigeria vary both across income groups and states. This implies that there are differences in economic behaviour, endowments and the impact of this trade policy on the state

1 See Singh et al. [40] for the farm household model, a standard model, which is often used to measure change in households' welfare. economies. This analysis only considers the effects of price changes on poverty.

This study uses different households' survey conducted by the National Bureau of Statistics (NBS) such as the Generalized Household survey 2006 - 2009, Harmonized National Living Survey (HNLSS) 2009, General Households' Survey - Panel (Post Planting) and General Households' Survey - Panel (Post - Harvest) 2010 - 2011. These surveys provided information on expenditure, income, characteristics of households, sector of occupation, education and gender.

The tariffs data are sourced from the World Integrated Trade Solution (WITS) database, while the world prices were obtained from the World Bank commodity price datasheet at the nominal US dollar, which was converted to domestic currency at the prevailing exchange rates. The domestic consumer prices were also sourced from the National Bureau of Statistics ${ }^{3}$. All Nigerian states including the Federal Capital Territory (FCT) are considered. Efforts were also made to categorize the states along their geopolitical zones in order to reflect policy direction and stimulate national strategical planning and programmes in this respect. There are six geopolitical zones in Nigeria, they are; Southwest, Southeast, South-south, Northwest, Northeast and North - central. Data for the pass - through covers the period 2006 to 2014.

Time dummy variable is included in the pass-through model. The differentials of tariff pass - through across time are capture by these fixed effects. The distance of each state to the nearest seaport was calculated using the Globe Feed Distance Calculator. Nigeria has 21 seaports that could be used for importation of goods to the country (Jaja, [41]). The major seaports are; Tin Can Island, Apapa, Kirikiri (Lagos), Warri (Delta), Port Harcourt (Rivers State) and Calabar (Cross River). Most seaports activities take place in Lagos and Rivers states ${ }^{4}$.

\section{Results and Discussion}

An analysis of the observed prices for the period between 2005 and $2014^{5}$ shows that there is a slight consistency in price movement across the states and years, which shows relative price adjustment stability in the agricultural products (see table 1). Some oscillations are observed in the variance of the log price across the states and years, suggesting that there is considerable price differential across and within the states over these years due to individual preferences, varying input costs, state endowment differentials and market regulations.

2 MHRS was dropped due to non - availability of variables of interest, especially households' wage income, sales among others.

3 This data is not available in any of their publication or online, but we requested for it through our contact at their Headquarters and we were given the data.

4 All these seaports are in the Southern part of the country.

5The commodities' prices were reported as obtained from the National Bureau of Statistic (NBS). The prices are averages for all states and at the national level. 
Table 1. Domestic prices ${ }^{6}$ by year and state, 2005-2014(log)

\begin{tabular}{|c|c|c|c|c|c|}
\hline \multirow{2}{*}{ State } & \multicolumn{5}{|c|}{ Agriculture } \\
\hline & 2005 & 2007 & 2009 & 2011 & 2014 \\
\hline Abia & $\begin{array}{c}5.283 \\
(1.102)\end{array}$ & $\begin{array}{c}5.418 \\
(1.160)\end{array}$ & $\begin{array}{c}5.580 \\
(1.145)\end{array}$ & $\begin{array}{c}5.738 \\
(1.270)\end{array}$ & $\begin{array}{c}5.902 \\
(0.614)\end{array}$ \\
\hline Adamawa & $\begin{array}{c}4.987 \\
(1.372)\end{array}$ & $\begin{array}{c}5.143 \\
((1.373)\end{array}$ & $\begin{array}{c}5.413 \\
(1.150)\end{array}$ & $\begin{array}{c}5.559 \\
(1.266)\end{array}$ & $\begin{array}{c}5.778 \\
(0.602)\end{array}$ \\
\hline Akwa lbom & $\begin{array}{c}5.194 \\
(1.067)\end{array}$ & $\begin{array}{c}5.445 \\
(1.165)\end{array}$ & $\begin{array}{c}5.615 \\
(1.125)\end{array}$ & $\begin{array}{c}5.861 \\
(1.258)\end{array}$ & $\begin{array}{c}5.858 \\
(0.595)\end{array}$ \\
\hline Anambra & $\begin{array}{c}5.136 \\
(1.221)\end{array}$ & $\begin{array}{c}5.380 \\
(1.166)\end{array}$ & $\begin{array}{c}5.616 \\
(1.232)\end{array}$ & $\begin{array}{c}5.712 \\
(1.251)\end{array}$ & $\begin{array}{c}5.817 \\
(0.571)\end{array}$ \\
\hline Bauchi & $\begin{array}{c}4.957 \\
(1.249) \\
\end{array}$ & $\begin{array}{c}5.082 \\
(1.332) \\
\end{array}$ & $\begin{array}{c}5.352 \\
(1.190) \\
\end{array}$ & $\begin{array}{c}5.90 \\
(1.336) \\
\end{array}$ & $\begin{array}{c}5.769 \\
(0.594) \\
\end{array}$ \\
\hline Bayelsa & $\begin{array}{c}5.266 \\
(1.006) \\
\end{array}$ & $\begin{array}{c}5.473 \\
(1.038) \\
\end{array}$ & $\begin{array}{c}5.612 \\
(1.063) \\
\end{array}$ & $\begin{array}{c}5.871 \\
(1.393) \\
\end{array}$ & $\begin{array}{c}5.900 \\
(0.621)\end{array}$ \\
\hline Benue & $\begin{array}{c}4.743 \\
(1.129) \\
\end{array}$ & $\begin{array}{c}5.178 \\
(1.423) \\
\end{array}$ & $\begin{array}{c}5.427 \\
(1.229) \\
\end{array}$ & $\begin{array}{c}5.722 \\
(1.393) \\
\end{array}$ & $\begin{array}{c}5.837 \\
(0.601) \\
\end{array}$ \\
\hline Borno & $\begin{array}{c}5.163 \\
(1.132)\end{array}$ & $\begin{array}{c}5.169 \\
(1.396) \\
\end{array}$ & $\begin{array}{c}5.337 \\
(1.230)\end{array}$ & $\begin{array}{c}5.516 \\
(1.189)\end{array}$ & $\begin{array}{c}5.812 \\
(0.608)\end{array}$ \\
\hline Cross River & $\begin{array}{c}5.236 \\
(1.140) \\
\end{array}$ & $\begin{array}{c}5.362 \\
(1.129) \\
\end{array}$ & $\begin{array}{c}5.522 \\
(1.124)\end{array}$ & $\begin{array}{c}5.847 \\
(1.184)\end{array}$ & $\begin{array}{c}5.870 \\
(0.604)\end{array}$ \\
\hline Delta & $\begin{array}{c}5.163 \\
(1.053) \\
\end{array}$ & $\begin{array}{c}5.432 \\
(1.110) \\
\end{array}$ & $\begin{array}{c}5.587 \\
(1.039) \\
\end{array}$ & $\begin{array}{c}5.812 \\
(1.196) \\
\end{array}$ & $\begin{array}{c}5.852 \\
(0.610)\end{array}$ \\
\hline Ebonyi & $\begin{array}{c}5.022 \\
(1.141)\end{array}$ & $\begin{array}{c}5.320 \\
(1.155)\end{array}$ & $\begin{array}{c}5.594 \\
(1.120)\end{array}$ & $\begin{array}{c}5.761 \\
(1.127)\end{array}$ & $\begin{array}{c}5.778 \\
(0.593)\end{array}$ \\
\hline Edo & $\begin{array}{c}5.190 \\
(1.101) \\
\end{array}$ & $\begin{array}{c}5.461 \\
(1.112) \\
\end{array}$ & $\begin{array}{c}5.568 \\
(1.150) \\
\end{array}$ & $\begin{array}{c}5.821 \\
(1.223) \\
\end{array}$ & $\begin{array}{c}5.821 \\
(0.589) \\
\end{array}$ \\
\hline Ekiti & $\begin{array}{c}5.133 \\
(1.262)\end{array}$ & $\begin{array}{c}5.312 \\
(1.296)\end{array}$ & $\begin{array}{c}5.657 \\
(1.357) \\
\end{array}$ & $\begin{array}{c}5.698 \\
(1.253)\end{array}$ & $\begin{array}{c}5.821 \\
(0.576)\end{array}$ \\
\hline Enugu & $\begin{array}{c}5.112 \\
(1.199)\end{array}$ & $\begin{array}{c}5.390 \\
(1.263) \\
\end{array}$ & $\begin{array}{c}5.612 \\
(1.171)\end{array}$ & $\begin{array}{c}5.635 \\
(1.246) \\
\end{array}$ & $\begin{array}{c}5.785 \\
(0.576)\end{array}$ \\
\hline Gombe & $\begin{array}{c}5.081 \\
(1.199) \\
\end{array}$ & $\begin{array}{c}.5 .120 \\
(1.396) \\
\end{array}$ & $\begin{array}{c}5.345 \\
(1.226) \\
\end{array}$ & $\begin{array}{c}5.546 \\
(1.298) \\
\end{array}$ & $\begin{array}{c}5.741 \\
(0.574)\end{array}$ \\
\hline Imo & $\begin{array}{c}5.128 \\
(1.161) \\
\end{array}$ & $\begin{array}{c}5.374 \\
(1.157) \\
\end{array}$ & $\begin{array}{c}5.534 \\
(1.186) \\
\end{array}$ & $\begin{array}{c}5.901 \\
(1.321) \\
\end{array}$ & $\begin{array}{c}5.846 \\
(0.584)\end{array}$ \\
\hline Jigawa & $\begin{array}{c}4.862 \\
(1.142) \\
\end{array}$ & $\begin{array}{c}4.952 \\
(1.246) \\
\end{array}$ & $\begin{array}{c}5.298 \\
(1.189) \\
\end{array}$ & $\begin{array}{c}5.486 \\
(1.184) \\
\end{array}$ & $\begin{array}{c}5.787 \\
(0.591) \\
\end{array}$ \\
\hline Kaduna & $\begin{array}{c}4.915 \\
(1.253)\end{array}$ & $\begin{array}{c}5.067 \\
(1.377) \\
\end{array}$ & $\begin{array}{c}5.423 \\
(1.289) \\
\end{array}$ & $\begin{array}{c}5.635 \\
(1.353) \\
\end{array}$ & $\begin{array}{c}5.775 \\
(0.580)\end{array}$ \\
\hline Kano & $\begin{array}{c}4.991 \\
(1.175) \\
\end{array}$ & $\begin{array}{c}4.984 \\
(1.338) \\
\end{array}$ & $\begin{array}{c}5.432 \\
(1.396) \\
\end{array}$ & $\begin{array}{c}5.537 \\
(1.270) \\
\end{array}$ & $\begin{array}{c}5.912 \\
(0.683)\end{array}$ \\
\hline Katsina & $\begin{array}{c}4.947 \\
(1.253) \\
\end{array}$ & $\begin{array}{c}5.052 \\
(1.309) \\
\end{array}$ & $\begin{array}{c}5.384 \\
(1.304) \\
\end{array}$ & $\begin{array}{c}5.591 \\
(1.371) \\
\end{array}$ & $\begin{array}{c}5.912 \\
(0.683)\end{array}$ \\
\hline Kebbi & $\begin{array}{c}4.987 \\
(1.189)\end{array}$ & $\begin{array}{c}5.084 \\
(1.288)\end{array}$ & $\begin{array}{c}5.397 \\
(1.185)\end{array}$ & $\begin{array}{c}5.598 \\
(1.285) \\
\end{array}$ & $\begin{array}{c}5.790 \\
(0.575)\end{array}$ \\
\hline Kogi & $\begin{array}{c}5.253 \\
(1.039) \\
\end{array}$ & $\begin{array}{c}5.132 \\
(1.180) \\
\end{array}$ & $\begin{array}{c}5.632 \\
(1.261) \\
\end{array}$ & $\begin{array}{c}5.777 \\
(1.293) \\
\end{array}$ & $\begin{array}{c}5.838 \\
(0.598)\end{array}$ \\
\hline Kwara & $\begin{array}{c}5.037 \\
(1.294)\end{array}$ & $\begin{array}{c}5.141 \\
(1.376)\end{array}$ & $\begin{array}{c}5.481 \\
(1.254)\end{array}$ & $\begin{array}{c}5.699 \\
(1.344)\end{array}$ & $\begin{array}{c}5.838 \\
(0.592)\end{array}$ \\
\hline Lagos & $\begin{array}{c}5.133 \\
(1.348)\end{array}$ & $\begin{array}{c}5.361 \\
(1.184) \\
\end{array}$ & $\begin{array}{c}5.658 \\
(1.233)\end{array}$ & $\begin{array}{c}5.780 \\
(1.237)\end{array}$ & $\begin{array}{c}5.793 \\
(0.589) \\
\end{array}$ \\
\hline Nasarawa & $\begin{array}{c}5.001 \\
(1.348) \\
\end{array}$ & $\begin{array}{c}5.158 \\
(1.445) \\
\end{array}$ & $\begin{array}{c}5.472 \\
(1.284) \\
\end{array}$ & $\begin{array}{c}5.701 \\
(1.460) \\
\end{array}$ & $\begin{array}{c}5.885 \\
(0.627)\end{array}$ \\
\hline Niger & $\begin{array}{c}5.003 \\
(1.306)\end{array}$ & $\begin{array}{c}5.131 \\
(1.332)\end{array}$ & $\begin{array}{c}5.385 \\
(1.180)\end{array}$ & $\begin{array}{c}5.618 \\
(1.318) \\
\end{array}$ & $\begin{array}{c}5.782 \\
(0.578)\end{array}$ \\
\hline Ogun & $\begin{array}{c}5.113 \\
(1.162) \\
\end{array}$ & $\begin{array}{c}5.245 \\
(1.246) \\
\end{array}$ & $\begin{array}{c}5.583 \\
(1.180) \\
\end{array}$ & $\begin{array}{c}5.730 \\
(1.201) \\
\end{array}$ & $\begin{array}{c}5.786 \\
(0.569) \\
\end{array}$ \\
\hline Ondo & $\begin{array}{c}5.124 \\
(1.204)\end{array}$ & $\begin{array}{c}5.278 \\
(1.282) \\
\end{array}$ & $\begin{array}{c}5.514 \\
(1.197)\end{array}$ & $\begin{array}{c}5.721 \\
(1.238) \\
\end{array}$ & $\begin{array}{c}5.852 \\
(0.572)\end{array}$ \\
\hline Osun & $\begin{array}{c}5.157 \\
(1.262) \\
\end{array}$ & $\begin{array}{c}5.216 \\
(1.408) \\
\end{array}$ & $\begin{array}{c}5.465 \\
(1.256) \\
\end{array}$ & $\begin{array}{c}5.648 \\
(1.301) \\
\end{array}$ & $\begin{array}{c}5.820 \\
(0.587)\end{array}$ \\
\hline Oyo & $\begin{array}{c}5.013 \\
(1.250) \\
\end{array}$ & $\begin{array}{c}5.175 \\
(1.326) \\
\end{array}$ & $\begin{array}{c}5.480 \\
(1.231) \\
\end{array}$ & $\begin{array}{c}5.668 \\
(1.318) \\
\end{array}$ & $\begin{array}{c}5.811 \\
(0.605)\end{array}$ \\
\hline Plateau & 5.014 & 5.143 & 5.577 & 5.669 & 5.873 \\
\hline
\end{tabular}

6 Note that the prices are in nominal terms. 


\begin{tabular}{|c|c|c|c|c|c|}
\hline & (1.197) & (1.411) & $(1.338)$ & $(1.345)$ & $(0.631)$ \\
\hline Rivers & $\begin{array}{c}5.222 \\
(1.197)\end{array}$ & $\begin{array}{c}5.422 \\
(1.179)\end{array}$ & $\begin{array}{c}5.633 \\
(1.155)\end{array}$ & $\begin{array}{c}5.841 \\
(1.242)\end{array}$ & $\begin{array}{c}5.868 \\
(0.609)\end{array}$ \\
\hline Sokoto & $\begin{array}{c}5.076 \\
(1.313)\end{array}$ & $\begin{array}{c}5.068 \\
(1.119)\end{array}$ & $\begin{array}{c}5.454 \\
(1.155)\end{array}$ & $\begin{array}{c}5.652 \\
(1.307)\end{array}$ & $\begin{array}{c}5.737 \\
(0.554) \\
\end{array}$ \\
\hline Taraba & $\begin{array}{c}4.910 \\
(1.278)\end{array}$ & $\begin{array}{c}5.172 \\
(1.375)\end{array}$ & $\begin{array}{c}5.336 \\
(1.136)\end{array}$ & $\begin{array}{c}5.609 \\
(1.281)\end{array}$ & $\begin{array}{c}5.762 \\
(0.579)\end{array}$ \\
\hline Yobe & $\begin{array}{c}4.853 \\
(1.019)\end{array}$ & $\begin{array}{c}5.105 \\
(1.238) \\
\end{array}$ & $\begin{array}{c}5.420 \\
(1.242)\end{array}$ & $\begin{array}{c}5.711 \\
(1.400)\end{array}$ & $\begin{array}{r}5.730 \\
(0.516) \\
\end{array}$ \\
\hline Zamfara & $\begin{array}{c}4.929 \\
(1.084) \\
\end{array}$ & $\begin{array}{c}4.993 \\
(1.273) \\
\end{array}$ & $\begin{array}{c}5.354 \\
(1.200) \\
\end{array}$ & $\begin{array}{c}5.604 \\
(1.343) \\
\end{array}$ & $\begin{array}{c}5.852 \\
(0.624) \\
\end{array}$ \\
\hline $\begin{array}{l}\text { Federal Capital } \\
\text { Territory/Abuja }\end{array}$ & $\begin{array}{c}5.066 \\
(1.260)\end{array}$ & $\begin{array}{c}5.252 \\
(1.368)\end{array}$ & $\begin{array}{c}5.585 \\
(1.317)\end{array}$ & $\begin{array}{c}5.769 \\
(1.443)\end{array}$ & $\begin{array}{r}5.810 \\
(0.599) \\
\end{array}$ \\
\hline National & $\begin{array}{c}5.059 \\
(1.137)\end{array}$ & $\begin{array}{c}5.222 \\
(1.219)\end{array}$ & $\begin{array}{c}5.496 \\
(1.155)\end{array}$ & $\begin{array}{c}5.585 \\
(1.161)\end{array}$ & $\begin{array}{c}5.818 \\
(0.534)\end{array}$ \\
\hline
\end{tabular}

Source: Author's estimates.

Notes: Nominal domestic prices are the unit values that were sourced from NBS commodity prices and averaged across the states. Rice, maize, sorghum, chicken, soya beans, meat, fish, groundnut, orange and shrimps were used for agricultural commodities, while manufactured products consist of processed items.

Table 2. Tariff pass-through to domestic prices

\begin{tabular}{|c|c|c|c|c|}
\hline \multirow{2}{*}{ Agriculture } & \multicolumn{4}{|c|}{ Dependent Variable - Log Prices } \\
\hline & 1 & 2 & 3 & 4 \\
\hline Constant & $\begin{array}{c}-1.4507 * * * \\
(0.1682)\end{array}$ & $\begin{array}{c}-1.0552 * * * \\
(0.1702)\end{array}$ & $\begin{array}{c}-1.4960 * * * \\
(0.1674)\end{array}$ & $\begin{array}{c}-1.0983 * * * \\
(0.1694)\end{array}$ \\
\hline Tariffs & $\begin{array}{c}0.7377^{* * *} \\
(0.1120)\end{array}$ & $\begin{array}{c}0.9910^{* * *} \\
(0.1152)\end{array}$ & $\begin{array}{c}0.3694 * * \\
(0.1534) \\
\end{array}$ & $\begin{array}{c}0.6570 * * * \\
(0.1533)\end{array}$ \\
\hline World Price & $\begin{array}{c}0.3133 * * * \\
(0.0141)\end{array}$ & $\begin{array}{c}0.2652^{* * *} \\
(0.0149)\end{array}$ & $\begin{array}{c}0.3168^{* * *} \\
(0.0140)\end{array}$ & $\begin{array}{c}0.2687^{* * *} \\
(0.0148)\end{array}$ \\
\hline Domestic substitute price & $\begin{array}{c}0.7565^{* * *} \\
(0.0107)\end{array}$ & $\begin{array}{c}0.7319^{* * *} \\
(0.0109)\end{array}$ & $\begin{array}{c}0.7751 * * * \\
(0.0113)\end{array}$ & $\begin{array}{c}0.7503 * * * \\
(0.0114)\end{array}$ \\
\hline Tariff*Distance & & & $\begin{array}{c}-0.0011 * * * \\
(0.0004) \\
\end{array}$ & $\begin{array}{c}-0.0011 * * * \\
(0.0004) \\
\end{array}$ \\
\hline Tariff*Distance Squared & & & $\begin{array}{c}5.08 \mathrm{e}-06^{* * *} \\
(1.12 \mathrm{e}-06)\end{array}$ & $\begin{array}{c}5.24 \mathrm{e}-06 * * * \\
(1.12 \mathrm{e}-06)\end{array}$ \\
\hline Wald Chi-square & $\begin{array}{l}5925.85 \\
(0.0000) \\
\end{array}$ & $\begin{array}{l}6194.61 \\
(0.0000) \\
\end{array}$ & $\begin{array}{l}6086.70 \\
(0.0000)\end{array}$ & $\begin{array}{l}6351.66 \\
(0.0000)\end{array}$ \\
\hline Observation & 1273 & 1273 & 1273 & 1273 \\
\hline
\end{tabular}

Source: Author's estimates.

Note: All variables are in log. The heteroskedasticity in the standard errors has been corrected and is shown in the parentheses. The significant variables are denoted by the*,** and $* * *$ at 10,5 , and 1 per cent significance levels, respectively. The tariff-distance interaction isolated empirically the local effects of tariff transmission (see Nicita, [5]). The interaction of log of tariff and state is used in specification (1) to get the pass through across the states (see Marchand, [6]).

The tariff pass-through is presented in table 2 for the agricultural goods ${ }^{7}$. The table presents the estimated results for four different specifications of equation (4): estimation without tariffs-distance interaction in column $1^{8}$, estimation without tariffs-distance interaction, but with time fixed effects in column 2, estimation with tariffs-distance interaction in column 3 and estimation with tariffs-distance interaction and time fixed effects in column 4. The estimations are performed using the feasible generalized least square (FGLS) cross-sectional time series, with correction for any heteroscedasticity and autocorrelation in the standard errors. ${ }^{9}$ The table shows evidence of significant pass-through in the estimates of prices of all agricultural goods and the tariff pass through

7 The producer prices are the domestic substitute prices, which are significant in all estimates.

8 It is from this specification that the study got the state pass-through through the interaction of tariff and state variables (see Marchand, [6]). 9The Hausman-Taylor estimation reveals that the instrument variables are not required. tends to increase substantially with the inclusion of time fixed effects. This indicates that the pass-through in agricultural sector is time -specific. The tariff-distance interaction, which is another variable of interest, is statistically significant with the expected sign.

The coefficient of the tariff pass-through is estimated to be between 73 and 99 percent. The results show that any exclusion of time fixed effects reduces the estimated pass-through effect for agricultural goods, indicating that the pass-through depends on time, that is, that agricultural prices tend to change with time, which confirms the findings of Marchand [6].

The results also indicate that the consumers of agriculture goods benefited from the tariff reduction through the ECOWAS-CET given the magnitude of the pass-through. Thus, when the distance is interacted with the tariffs, pass-through is found to significantly decline with distance from the seaports. All the coefficients of interest (tariffs and tariff-distance) have the expected signs 
and significant. All standard errors are militated against heteroscedasticity in the FGLS estimation.

\subsection{Pass-Through Estimates}

Using specification (1) ${ }^{10}$ in table 2 , the pass-through in the country is estimated at $74 \%$ of the goods ${ }^{11}$. These pass-through estimates are in a relatively high range in line with the $33 \%$ for agriculture and $27 \%$ for manufacturing in Nicita [5]. Campa and Goldberg [42] found a $40 \%$ pass-through for manufacturing in the United States and $70 \%$ in Germany. Frankel et al. [43] obtained a 50\% pass-through to imported prices in a group of developing countries, while Marchand [6] reported between 33 and 49\% for rural areas and 64 and $68 \%$ for urban areas. The world price pass-through has significant positive effects in all the estimations. In addition, the elasticities of world prices range between 27 and $31 \%$.

The results also present the elasticities of the interaction of tariffs and distance, which show the extent to which trade costs across distance affected tariff pass-through. The estimates of tariff-distance interaction show that there are relative regional differences in prices of agricultural goods. This is a different result from Nicita [5], who found regional differences in manufactured goods but no difference across states in agricultural goods. The tariff pass-through across domestic markets in agricultural goods prices is statistically significant, indicating that the impact of the tariff reduction is significantly transmitted to consumers in domestic markets across states. In other words, the consumers of agricultural goods benefited from the ECOWAS CET. States closer to ports are found to be more exposed to the impact of changes in agricultural tariffs. Considering the state/regional differences, the tariff pass-through at the border is 66 percent for agricultural sector, which declined to $0.1 \%$ at 100 kilometers from the port or border of entry ${ }^{12}$. The decline in the tariff pass-through as one gets farther away from ports of entry or borders is due to the associated trade costs, corruption, inadequate trade facilitation and most importantly the very poor state of infrastructure, which reduce household consumption gains from the tariff reduction and income loss for producers.

There is marginal difference in the tariff pass-through to domestic prices across states. Table 3 presents state-specific tariff elasticities that were obtained from the specification (4) of table $2 .{ }^{13}$ The results are very similar to Marchand [6] where many of the coastal states have

10 This estimation was done without the interaction of distance with tariffs and time fixed effects.

11 These estimates are from specification (1) in table 2 (see Nicita, [5]). 12 Tariff pass-through at the border is the coefficient of tariffs in specification (4) in Table 2, while the estimate of tariff-distance interaction gave the change in tariff pass-through for every kilometer distance from the port or border.

13 The state specific pass through elasticities was obtained by finding the derivatives of equation (4) with respect to tariff and then inserted the value of the coefficients from specification (4) in table 2 before estimating it for each state. relatively significant and positive pass-through elasticities. This indicates that households that are close to ports of entry benefit significantly from the tariff reduction. The relatively increased pass-through in the Lagos and Rivers states in agriculture is due to the location of functional ports of entry there. In fact, Lagos ports recorded more than $70 \%$ of port activities in Nigeria (Jaja, [41]). In addition, smuggling activities at the ports and borders in these states have a significant effect on these elasticities. ${ }^{14}$ Smuggled goods, especially agricultural goods, avoid tariffs and are cheaper than tariffed goods. ${ }^{15}$ These smuggling activities are the result of Nigeria's porous borders (Adeola and Fayomi, [44]; Ohai, [46]). ${ }^{16}$ Adamawa and Borno states have exceptional high pass-through due to the porous borders in both states ${ }^{17}$.

Some selected details about the impact of the ECOWAS CET are presented in Table 3. It could be seen that the CET has resulted in an increase of overall household welfare of 6.9 per cent at the national level. The gains originate from the expenditure basket $(8.9 \%)$, which compensated the losses incurred from sales of agricultural $(1.9 \%)$, for households. The losses of profit from goods sold due to price reductions of agricultural goods are small, on average $(1.9 \%)$. Disaggregating the effects indicates that there are differences across geopolitical zones and states as well as between rural and urban areas.

In addition, the average total gains are presented in figure 1. This CET benefitted all income groups, and households at lower income levels experienced higher welfare gains. In terms of change in real income due to sales and prices in the sector across income percentiles, it could be seen from the figure that all households benefited from lower expenditure basket due to lower prices, with those at the $80^{\text {th }}$ and $100^{\text {th }}$ percentile gaining less and those in the lowest income percentile gaining the most. Household real income changed due to the fact that agricultural sales were negative for households relying mostly on sales of these products. The poorest households in Nigeria on the average benefitted more from the CET than the richest households due to more composition of agricultural goods in their basket of commodities expenditure. Households are affected negatively from tariff pass-through, due to loss of income from product sales. High-income households experienced less welfare gains due to the little composition of agricultural commodities in their expenditure bundles, despite the fact that they are less

14 There are 1,497 illegal and 84 legal routes (borders) to Nigeria (Premium Times, [45]).

15 Smuggled goods totally evade tariffs, thereby gaining access to the country without tariff payment, which reduces their prices in the market compared to taxed goods. Also, domestic producers of these goods are negatively affected, as there is a loss of profit due to the competition from the cheap goods. Nigeria's rice millers and producers, in particular, often complain about this problem.

16This is the reason for the recent directive by the federal government through the Nigerian Custom Service that all rice importation must go through the seaports.

17 The Boko Haram militants used these states as their operation based because of the easy access to neighbouring countries due to the porous and illegal borders. 
affected from income loss from sales of agricultural products.

Table 3. Overview of results, 2006-2014 (per cent)

\begin{tabular}{|c|c|c|c|c|c|c|c|c|}
\hline & \multirow{2}{*}{$\begin{array}{c}\begin{array}{c}\text { Pass-throu } \\
\text { gh }\end{array} \\
\text { Agriculture }\end{array}$} & \multicolumn{2}{|c|}{ Income share } & \multicolumn{2}{|c|}{ Expenditure share } & \multicolumn{2}{|c|}{$\begin{array}{l}\text { Changes in real } \\
\text { income due to: }\end{array}$} & \multirow{2}{*}{$\begin{array}{c}\begin{array}{c}\text { Overall changes in } \\
\text { real income due to } \\
\text { the Common } \\
\text { External Tariff: }\end{array} \\
\text { Total }\end{array}$} \\
\hline & & Agriculture & $\begin{array}{c}\text { Manufac } \\
\text { turing }\end{array}$ & Agriculture & $\begin{array}{l}\text { Manufacturi } \\
\text { ng }\end{array}$ & $\begin{array}{l}\text { Agricultu } \\
\text { re sales }\end{array}$ & Expenses & \\
\hline North-Central & - & 6.1 & 70.3 & 63.5 & 38.4 & -1.7 & 13.3 & 9.5 \\
\hline Benue & 45.23 & 22.13 & 63.12 & 59.54 & 38.29 & -7.97 & 20.31 & 13.11 \\
\hline Kogi & 44.15 & 16.13 & 82.19 & 65.16 & 32.47 & -1.47 & 22.92 & 21.21 \\
\hline Kwara & 43.12 & 11.04 & 81.11 & 66.68 & 31.36 & 0.11 & -0.31 & -0.21 \\
\hline Nasarawa & 44.32 & 0.24 & 45.22 & 69.36 & 31.79 & 0.01 & 9.39 & 8.28 \\
\hline Niger & 43.51 & 0.02 & 87.76 & 68.06 & 33.55 & 0.02 & 3.56 & 3.56 \\
\hline Plateau & 45.12 & 2.20 & 53.12 & 59.37 & 38.19 & -0.70 & 17.83 & 13.03 \\
\hline $\begin{array}{c}\text { Federal Capital } \\
\text { Territory } \\
\end{array}$ & 46.11 & 3.48 & 53.12 & 46.55 & 52.52 & -0.24 & 3.45 & 3.74 \\
\hline North-East & - & 17.4 & 75.5 & 67.8 & 31.9 & -4.8 & 17.8 & 10.3 \\
\hline Adamawa & 52.29 & 27.13 & 74.43 & 65.74 & 34.63 & -8.70 & 21.76 & 12.32 \\
\hline Bauchi & 55.18 & 2.32 & 73.30 & 65.10 & 32.87 & -0.56 & 8.19 & 8.83 \\
\hline Borno & 143.21 & 20.41 & 78.43 & 74.23 & 24.87 & -4.39 & 16.31 & 12.51 \\
\hline Gombe & 86.42 & 22.40 & 57.43 & 63.45 & 35.90 & -5.76 & 13.26 & 7.53 \\
\hline Taraba & 51.17 & 26.12 & 59.35 & 79.09 & 19.70 & -7.33 & 22.28 & 15.38 \\
\hline Yobe & 87.38 & 7.61 & 95.34 & 55.06 & 45.89 & -1.8 & 15.90 & 12.32 \\
\hline North-West & - & 9.6 & 78.6 & 71.8 & 29.7 & -0.5 & 13.8 & 10.9 \\
\hline Jigawa & 72.15 & 7.23 & 78.10 & 66.58 & 33.14 & -0.73 & 6.37 & 5.67 \\
\hline Kaduna & 52.29 & 13.19 & 63.21 & 68.10 & 33.10 & -3.44 & 16.38 & 14.06 \\
\hline Kano & 71.16 & 9.22 & 74.04 & 79.01 & 21.54 & -1.04 & 13.42 & 11.99 \\
\hline Katsina & 77.59 & 0.23 & 86.86 & 59.54 & 39.16 & 0.02 & 11.56 & 12.05 \\
\hline Kebbi & 52.10 & 14.28 & 83.87 & 76.39 & 22.49 & -1.01 & 5.13 & 4.19 \\
\hline Sokoto & 62.67 & 21.88 & 70.53 & 68.18 & 37.67 & -6.94 & 21.24 & 14.86 \\
\hline Zamfara & 53.88 & 11.80 & 60.87 & 87.34 & 11.81 & 1.37 & 10.46 & 9.54 \\
\hline South-East & - & 15.4 & 66.3 & 57.9 & 43.6 & -0.9 & 2.6 & 3.2 \\
\hline Abia & 53.17 & 3.18 & 65.78 & 52.42 & 43.33 & -0.08 & 1.75 & 1.76 \\
\hline Anambra & 43.17 & 21.60 & 65.20 & 62.54 & 39.39 & -0.68 & 1.65 & 1.43 \\
\hline Ebonyi & 49.69 & 0.28 & 78.14 & 38.58 & 63.21 & 0.01 & 0.56 & 0.35 \\
\hline Enugu & 44.49 & 11.00 & 56.65 & 54.96 & 42.24 & -0.29 & 1.23 & 0.76 \\
\hline Imo & 53.04 & 24.85 & 58.92 & 73.10 & 26.32 & -2.54 & 7.35 & 4.89 \\
\hline South-South & - & 11.3 & 61.9 & 59.9 & 38.2 & -3.6 & 13.7 & 9.4 \\
\hline Akwa Ibom & 56.04 & 10.23 & 32.41 & 59.22 & 38.87 & -1.99 & 11.65 & 8.68 \\
\hline Bayelsa & 57.33 & 48.11 & 46.28 & 65.01 & 33.82 & -24.82 & 33.76 & 8.35 \\
\hline Cross River & 52.54 & 15.46 & 85.59 & 61.34 & 36.91 & -2.20 & 8.74 & 6.53 \\
\hline Delta & 57.16 & 17.17 & 82.31 & 61.12 & 37.32 & -3.28 & 11.45 & 7.91 \\
\hline Edo & 46.88 & 3.11 & 81.54 & 63.21 & 35.52 & -0.28 & 12.56 & 10.32 \\
\hline Rivers & 68.37 & 4.12 & 53.56 & 55.54 & 45.17 & -0.77 & 9.22 & 9.98 \\
\hline South-West & - & 9.8 & 83.0 & 58.6 & 45.3 & 0.5 & 3.2 & 3.8 \\
\hline Ekiti & 44.28 & 13.03 & 75.56 & 56.89 & 41.38 & -0.26 & 1.84 & 1.56 \\
\hline Lagos & 68.62 & 7.23 & 89.67 & 53.27 & 49.34 & -0.02 & 7.87 & 6.23 \\
\hline Ogun & 67.67 & 5.11 & 83.22 & 53.30 & 45.16 & 0.30 & 3.91 & 4.61 \\
\hline Ondo & 49.44 & 23.11 & 79.52 & 65.00 & 34.39 & -0.14 & 1.83 & 2.09 \\
\hline Osun & 59.30 & 11.06 & 77.04 & 58.90 & 39.35 & 1.24 & -4.14 & -3.01 \\
\hline Oyo & 64.57 & 8.04 & 79.05 & 57.08 & 42.50 & 0.23 & -0.33 & -0.10 \\
\hline National & 61.8 & 14.6 & 72.3 & 65.4 & 37.9 & -1.4 & 9.8 & 7.8 \\
\hline Rural & - & 24.9 & 60.0 & 77.4 & 20.1 & -6.70 & 21.9 & 16.3 \\
\hline Urban & - & 11.7 & 70.6 & 64.4 & 38.1 & -1.9 & 8.9 & 7.8 \\
\hline
\end{tabular}




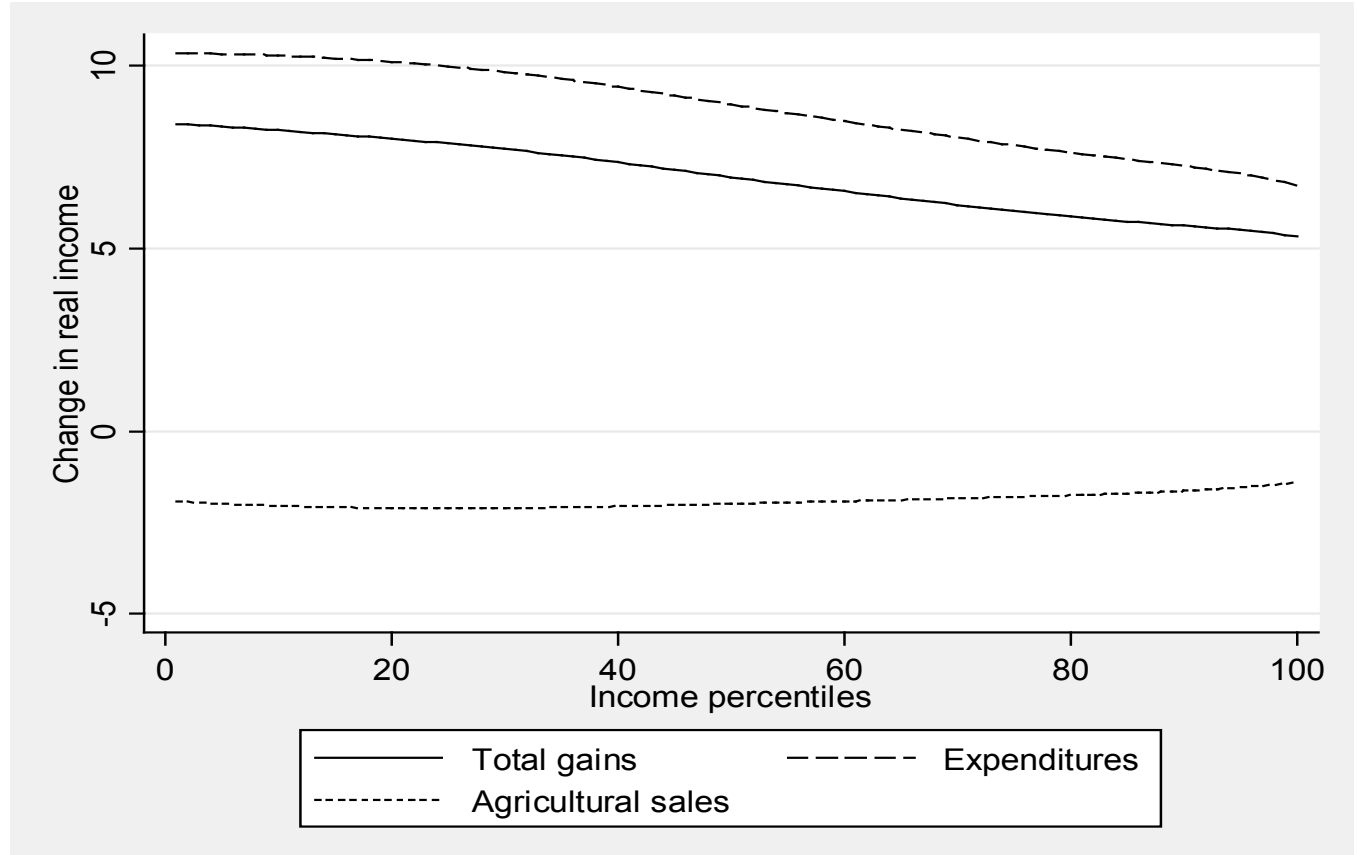

Source: Author's estimates.

Figure 1. Change in real income

A geographical distribution of welfare gains due to the CET indicates that, households in the Northern states benefited more than the Southern states due to higher expenditure gains from the porous borders with neighbouring countries. Further, the overall change in real income due to the CET in the agricultural sector indicates that the producers in this sector were adversely affected due to the level of pass-through, which is generally high. Although, CET negatively affected agricultural products' producers; however, consumers in the sector were better-off due to the availability of varieties and cheaper goods.

This paper also finds that the effects of this trade policy vary along the income distribution. The mean expenditure gains ${ }^{18}$ across income percentiles are shown in Figure $1^{19}$.On average, all household income groups had expenditure gains, but to varying degree.

\section{Conclusions}

This paper has examined the extent to which households are affected by the Common External Tariff of the Economic Community of West African States. The empirical analysis considered the poverty effects of the CET from the perspective of households as producers, consumers, and its transmission from domestic prices. The results show that the ECOWAS-CET reduced domestic

18 This examines the consumption channels of households, in terms of their access to product varieties at cheaper prices.

19 The figure shows change in real income due to expenditure, agricultural and manufacturing sales changes. prices of agricultural goods. In fact; the findings indicate that the CET has so far had a net positive effect on households in Nigeria, largely due to the gains from expenditure. The expenditure gains from the CET did outweigh the loss incurred in their purchasing power. Thus, household's welfare relatively was improved from the trade policy, particularly for the poor households in the rural areas, however, neither did high -income households made net loss from it. Some groups of households whose income depend largely on activities in the sector, specifically product sales, have seen a depletion of their purchasing power.

In spite the net positive effects, the paper found differences in the distribution of these welfare gains across states, geopolitical zones, and income groups. Richer households experienced less welfare gains than poorer households. The welfare of rural households was better than that of urban households and for male than female. Rural households' producers in states with ports of entry and near borders had their purchasing power more eroded than did households in the urban areas. Consumers in states with ports of entry are more exposed to goods available at relatively lower prices due to the CET than other states. Thus, the paper provides evidence that domestic price transmission, household characteristics, and the trade costs are significant in assessing the welfare effects of trade policies in Nigeria.

Thus, to reduce the income loss to households due to the CET, especially households in the rural areas, the government needs to introduce a policy of zero tolerance for smuggling and close illegal routes and borders. Smuggling exposes domestic producers to external 
producers against which they do not have the capacity to compete, and thereby leads to the depletion of profits from sales of goods. Further, the capacity of producers should be enhanced through an informed, integrated, and inclusive domestic policy that stimulates productivity and value addition. The government should boost investment in vital sectors of the economy by improving infrastructure, access to finance, producers' capacity, level of education, science and technology, land acquisition, etc.

\section{Acknowledgements}

The article is an excerpt from a project on Trade and Poverty sponsored by UNCTAD Virtual Institute. The author wish to thank the following scholars for their comments and contributions: Alessandro Nicita, Pierguiseppe Fortunato, Marco Fugazza, Nicolas Depetris and Nina Pavcnik. Also, I appreciate the supports from Ms. Vlasta Macku and Mr. Suleman Adebayo Audu.

\section{REFERENCES}

[1] World Bank. Nigeria: The Challenges of Growth with Inclusion, World Bank, Washington, 1996.

[2] National Bureau of Statistics (NBS) database (Assessed in May 2017). Available at www.nigerianstat.gov.ng.

[3] World Bank Database (Assessed in May 2017). Available at: http://data.worldbank.org/indicator/SI.POV.NAHC?locatio $\mathrm{ns}=\mathrm{NG}$

[4] A. Nicita. Who Benefited from Trade Liberalization in Mexico? Measuring the Effects on Household Welfare, World Bank Policy Research Working Paper 3265. Washington: World Bank. 2004.

[5] A. Nicita. The Price Effect of Tariff Liberalization: Measuring the Impact on Household Welfare, Journal of Development Economics, Vol. 89, $\mathrm{N}^{\mathrm{O}} 1$, pp.19-27, 2009.

[6] B.U. Marchand. Tariff Pass-through and the Distributional Effects of Trade Liberalization, Journal of Development Economics, Vol. 99, N², pp.65-281, 20, 2012.

[7] P. Topalova. Trade Liberalization, Poverty and Inequality: Evidence from Indian Districts, NBER Working Paper No. 11614.Cambridge, MA: National Bureau of Economic Research, 2005.

[8] P. Topalova. Factor Immobility and Regional Impacts of Trade Liberalization: Evidence on Poverty from India, America Economic Journal: Applied Economic, Vol. 2, $\mathrm{N}^{\mathrm{o}}$.4, pp.1-41, 2010.

[9] G. Porto. Using Survey Data to Assess the Distributional Effects of Trade Policy, Journal of International Economics, Vol. 70, Nº.1, pp.140-160, 2006.

[10] M. Castilho, M. Menendez, and A. Sztulman. Trade Liberalization, Inequality, and Poverty in Brazilian States,
Poverty and Social Exclusion Working Paper No.2009-33, 2012.

[11] E.D. Balogun, and R.O. Dauda. Poverty and Employment Impact of Trade Liberalization in Nigeria: Empirical Evidence and Policy Implications, Munich Personal RePEc Archive Paper No. 41006, 2012.

[12] N.E. Urama, E.O. Nwosu, and G.C. Aneke. Lost Revenue Due to Trade Liberalization: Can Nigeria Recover Her Own? European Journal of Business and Management. Vol.4, $\mathrm{N}^{\mathrm{o}} .10$, pp.134-142, 2012.

[13] M.O. Oduh. Trade Openness and Output Variability in Nigeria: Implications for EU-ACP Economic Partnership Agreement, Developing Country Studies, Vol.2, N $\mathrm{N}^{\mathrm{o}} .7$, pp.73-83, 2012.

[14] A. Oyejide. The Impact of the ECOWAS Common External Tariffs (CET) on the Real Sector, 2012. Available at: http://www.manufacturingtodaynigeria.com/index.php/cove r/154-case-study/5318-the-impact-of-the-ecowas-commonexternal-tariffs-cet-on-the-real-sector-.

[15] M. Nwafor. Trade Liberalization and Poverty in Nigeria: Lessons from the Past, African Institute for Applied Economics, Awka, Nigeria, 2006.

[16] M. Nwafor, K. Ogujiuba and A. Adenikinju. The Impact of Trade Liberalization on Poverty in Nigeria: Micro Simulation in A CGE Model, Interim Report to the Poverty and Economic Policy Research Network, 2005.

[17] J.M. Marchat, and T. Rajhi. Estimates of the Impact of a Common External Tariff on the Nigerian Manufacturing Sector: Some Simulation Results based on Firm Level Data, World Bank Working Paper, 2004.

[18] C. Soludo and E. Oji. Does Trade Openness Make Sense at This Time in Nigeria? Paper prepared for the TRADEMAC Trade and Macroeconomic Working Group, 2003.

[19] O.I. Kareem. The Welfare Impact in Nigeria of the Common External Tariff of ECOWAS: A distributional Effects Analysis" in United Nations Conference for Trade and Development (UNCTAD) (eds.) "Trade Policies, Household Welfare and Poverty Alleviation: Case Studies from the Virtual Institute Academic Network", United Nations, Geneva, Switzerland, 2014. Available at: http://unctad.org/en/PublicationChapters/gds2014d3_08_Ni geria_en.pdf

[20] A. Isik-Dikmelik. Trade Reforms and Welfare: An Ex-Post Decomposition of Income in Vietnam. World Bank Policy Research Working Paper 4049, 2006.

[21] G. Seshan. The Impact of Trade Liberalization on Household Welfare in a Developing Country with Imperfect Labor Markets. World Bank Policy Research Paper, No.3541, 2005.

[22] M. Castilho, M. Menendez and A., Sztulman. Trade Liberalization, Inequality, and Poverty in Brazilian States. World Development Vol. 40, No. 4, pp. 821-835, 2009.

[23] G. H. Hanson. Globalization, Labor Income, and Poverty in Mexico. NBER Working Paper 11027 67(1), p. 1-24, 2005.

[24] M. Shuaib. The Effect of Trade Liberalization on Poverty in Nigeria: A Micro-Macro Framework. International Economics Journal, vol. 31(1): 68-93, 2017. 
[25] M. Castilho, M. Menendez and A. Sztulman. Trade Liberalization, Inequality, and Poverty in Brazilian States. PSE Working Paper No.2009-33, 2012.

[26] G. Seshan. The Impact of Trade Liberalization on Household Welfare in a Developing Country with Imperfect Labor Markets. World Bank Policy Research Paper, No.3541, 2005.

[27] G. Porto. Estimating Household Responses to Trade Reforms: Net Consumers and Net Producers in Rural Mexico. World Bank Policy Research Working Paper 3695, 2005.

[28] O. Boysen. Border Price Shocks, Spatial Price Variation, and their Impacts on Poverty in Uganda. IIIS Discussion Paper No. 306, 2009.

[29] J. Gourdon, N. Maystre, and J., de Melo. Openness, inequality and poverty: Endowments matter. The Journal of International Trade \& Economic Development, Vol. 17, No. 3, pp.343-378, 2007.

[30] E. A. Ianchovichina, A. Nicita, and I. Soloaga. Trade Reform and Poverty: The Case of México. World Economy; 25, pp.945-972, 2002.

[31] O. I. Kareem. Household Welfare Effects of Economic Community of West African States' Common External Tariffs in Nigeria. Africagrowth Agenda, pp.8-11, 2015.

[32] D. Benjamin and A. Deaton. Household Welfare and the Pricing of Cocoa and Coffee in Côte d'Ivoire: Lessons from the Living Standards Surveys. The World Bank Economic Review, vol. 7, No 3, pp.293-318, 1993.

[33] S. Chen and M., Ravallion. (2003) "Household Welfare Impacts of China's Accession to the World Trade Organization.” Policy Research Working Paper 3040, World Bank, Washington, DC.

[34] M. Bussolo, R. De Hoyos and D., Medvedev. Global Income Distribution and Poverty in the Absence of Agricultural Distortions. World Bank Policy Research Working Paper 4849, 2009.

[35] R. de Arce, S. de Vicente, R. Mahia and E., Medina. Trade Liberalization and Poverty Reduction in Africa: Computable General Equilibrium Models Approach Literature Review. International Journal of Political Science and Development, Vol.2, No. 5, pp.90-96, 2014.

[36] M. L. Goff and R. J. Singh. Does Trade Reduce Poverty? A View from Africa. Journal of African Trade, vol. 1(2014), pp.
5-14, 2014.

[37] A. Seck, L. Cissokho, K. Makpayo and J., Haughton. How Important are Non-Tariff Barriers to Agricultural Trade within ECOWAS? Research Working Paper No.20103, Department of Economics, Suffolk University, 2010.

[38] K. Ajayi and P., Osafo-Kwaako. Research and Trade Policy Formulation: The Case of Nigeria's Adoption of the ECOWAS Common External Tariffs (CET). Latin America Trade Network Working Paper 78, 2007.

[39] Kuji Ltd. Comprehensive Review of the Nigerian Customs and Excise Tariff 1995 - 2001: Implications for Nigeria of The ECOWAS Common External Tariff and Nigeria's Obligations/commitments under WTO, ECOWAS, AGOA AND ACP-EU, 2012.

[40] I. Singh, L. Squire, and J. Strauss. Agricultural Household Models: Extensions, Applications and Policy. John Hopkins University Press, Baltimore, 1986.

[41] C.Y. Jaja. Freight Traffic at Nigeria's Seaports: Problems and Prospect, The Social Sciences, Vol.6, $\mathrm{N}^{\mathrm{o}} .4$, pp.250-258, 2011.

[42] J.M. Campa and L.S. Goldberg. Exchange Rate Pass-Through into Import Prices: A Macro or Micro Phenomenon? NBER Working Paper No. 8934. Cambridge, MA: National Bureau of Economic Research, 2002.

[43] J.A. Frankel, D.C. Parsley and S.J. Wei. Slow Pass-Through Around the World: A New Import for Developing Countries? Harvard University John F. Kennedy School of Government Faculty Research Working Paper No. RWP05-016, 2005.

[44] G.L. Adeola and O. Fayomi. The Political and Security Implication of Cross Border Migration Between Nigeria and Her Francophone Neighbours, International Journal of Social Sciences Tomorrow, Vol.1, Nº. 3, pp.12-23, 2012.

[45] Premium Times. Nigeria Has 1,497 Illegal Borders - Interior Minister," May 23, 2013. Available at http://premiumtimesng.com/news/135901-nigeria-has-1497 -illegal-borders-interior-minister.html

[46] C. Ohai. Seme Border: From Benin to Nigeria on Fabricated Vespa, Punch Newspaper, February 28, 2013. Available at: http://www.punchng.com/feature/seme-border-from-benin- $t$ o-nigeria-on-fabricated-vespa/

[47] World Bank. Commodity Price Data Database, 2013b. Availableathttp://data.worldbank.org/data-catalog/commodi ty-price-data.

i The paper is an excerpt from a project on Trade and Poverty sponsored by UNCTAD Virtual Institute. The author wish to thank the following scholars for their comments and contributions: Alessandro Nicita, Pierguiseppe Fortunato, Marco Fugazza, Nicolas Depetris and Nina Pavcnik. Also, I appreciate the supports from Ms. Vlasta Macku and Mr. Suleman Adebayo Audu. 